УДК 331.453

Ліщук М. Є., к.с.-г.н., доцент

Lishchuk M., PhD in Agricultural Sciences, Associate Professor https://orcid.org/0000-0001-9372-9252

Московчук А. Т., к.е.н., доцент

Moskovchuk A., PhD in Economic Science, Associate Professor

https://orcid.org/0000-0002-8355-0846

\title{
СИСТЕМА УПРАВЛІННЯ ОХОРОНОЮ ПРАЦІ В УКРАЇНІ: АНАЛІЗ СТАНУ ТА ПЕРСПЕКТИВ П̈Ї РЕФОРМУВАННЯ
}

\author{
Луцьький національний технічний університет
}

У матеріалах статті розглянуто стан системи управління охороною праці в України та перспективи ії реформування. Здійснено аналіз виробничого травматизму. Зазначено, що загальна його динаміка за 2015-2019 роки $є$ неоднозначною, проте стабільно зростає кількість смертельних нещасних випадків. Причинами такої ситуації може бути неефективність системи управління охороною праці.

Визначено стан імплементації міжнародних норм з охорони праці в національну нормативнозаконодавчу базу: транспортування міжнародних норм здійснюється фрагментарно, переважно у формі наказів, що не дозволить комплексно реформувати усі аспекти безпеки і гігієни праці та знизить ії впливовість. Охарактеризовано напрями удосконалення системи управління охороною праці 3 врахуванням ризикоорієнтованого підходу та законодавчих ініціатив з точки зору перспектив, загроз і недоліків.

Акцентовано увагу на тому, що результативність охорони праці залежить від мотивації учасників виробничого процесу. Зазначено, що більшість вітчизняних підприємств перебуває на другому рівні в культурі безпеки (за кривою Бредлі). Вони використовують контроль та примус до виконання необхідних правил. Це не дозволить розв'язати проблему, тому запропоновано поширювати колективну позитивну мотивацію, спрямовану на створення організаційних умов безпечної праці.

Виокремлено трансформаційні тенденції у сфері праці, які призведуть до змін у методах іiі охорони. Ними є технологічний прогрес, демографічна ситуація, кліматичні зміни і зміни організації праці. Окреслено основні напрями підвищення ефективності функціонування системи управління охороною праці в Україні, які врахують їі недоліки та адаптують до перспективних змін.

Ключові слова: система управління охороною праці, охорона праці, безпека та гігієна праці, виробничий травматизм, ризикоорієнтований підхід, конвенції та директиви 3 праці.

\section{OCCUPATIONAL SAFETY AND HEALTH MANAGEMENT SYSTEM IN UKRAINE: STATE ANALYSIS AND PROSPECTS OF REFORM}

\author{
Lutsk National Technical University
}

The article discusses the state of the labor protection management system in Ukraine and perspectives for its reform. An analysis of occupational injuries was performed. It is noted that its overall dynamics for 20152019 is ambiguous, but the number of fatal accidents is steadily increasing. The reasons for this may be the inefficiency of the occupational health and safety management system.

The state of the implementation of international labor protection norms in the national regulatory framework is determined. It is emphasized that implementation of international norms is performed fragmentary, mainly in a form of separate orders, which will not allow to make comprehensively reform of all aspects of occupational safety and health and an as such will reduce its influence. The directions of improvement of the system of labor protection management are described taking into account risk-oriented approach and legislative initiatives in terms of perspectives, threats and shortcomings.

It is emphasized that the effectiveness of labor protection depends on the motivation of participants of the production process. It is noted that most domestic enterprises are on the second level in the security culture (according to the Bradley curve). They use control and coercion to comply with the necessary rules. This will not solve the problem, so it is proposed to spread positive collective motivation supposed to create internal conditions for safe work.

Transformation tendencies in the sphere of work which will lead to changes in the methods of its protection are distinguished. They are technological progress, demographics, climate change and changes in 
work organization. The main directions of increasing the efficiency of labor protection management system in Ukraine functioning which take into account its disadvantages and adapt it to changes are outlined.

Key words: occupational safety and health management system, labor safety, occupational safety and health, occupational injuries, risk-oriented approach, conventions and labor directives.

Постановка проблеми у загальному вигляді i ïi зв'язок 3 важливими науковими та практичними завданнями. Демографічна ситуація, що склалася в Україні, характеризується низкою негативних тенденцій, які не сприяють забезпеченню високих темпів зростання економіки. Зокрема за період 2014-2019 рр. чисельність постійного населення скоротилась на 7,2\%, осіб працездатного віку (16-59 рр.) - на $10,8 \%$, осіб віком 60 років і старших зросла на $0,8 \%$. Отже, перевищення темпів скорочення працездатного населення над темпами зростання осіб пенсійного віку $є$ причиною того, що загальний коефіцієнт демографічного навантаження на 1000 осіб віком 16-59 рр. зріс від 344 осіб у 2014 р. до 388 у 2019 р. [1].

У зв’язку зі скороченням населення працездатного віку проблема збереження життя і здоров'я працівників набуває особливої ваги, а її розв'язання, в значній мірі, залежить від охорони і безпеки праці на виробництві. На це звертає увагу Міжнародна організація праці (МОП). Так, за іiі даними щоденно у світі від нещасних випадків на виробництві гине 1000 осіб і ще 6500 - від професійних захворювань. За період 20142017 рр. кількість смертей, пов'язаних з виробництвом, зросла з 2,33 млн у 2014 до 2,78 млн у 2017 р. Від втрат робочого часу світовий ВВП скоротився майже на 4\%, а у деяких країнах - більш ніж на 6\% [2].

Аналіз останніх досліджень, у яких започатковано вирішення проблеми. Економічні і соціальні проблеми охорони праці вивчалися багатьма вітчизняними та закордонними дослідниками, серед яких: А. А. Басанець, М. П. Гандзюк, Є. О. Геврик, Г. Г. Гогіташвілі, Л. О. Добровольський, В. Ц. Жидецький, П. О. Ізуїта, О. В. Касачева, Л. П. Керб, І. С. Кравченко, Ю. І. Кундієв, А. М. Нагорна, С. О. Обухов, І. В. Павлов , О. В. Савчук, М. Г. Федоренко, 3. М. Яремко та ін. Проте дослідження стану і тенденцій реформування системи управління охороною праці, виявлення основних проблемних питань та визначення шляхів їх розв'язання залишається актуальним.

Цілі статті. Метою дослідження є вдосконалення системи управління охороною праці в Україні з позиції відповідності міжнародним стандартам, виявлення недоліків, що виникають у процесі реформування, та окреслення перспектив підвищення іiі ефективності в умовах трансформаційних змін у сфері праці.

Виклад основного матеріалу дослідження 3 повним обгрунтуванням отриманих наукових результатів. Будь-яка система управління передбачає наявність пов'язаних між собою елементів 3 різними функціональними цілями, проте спрямованими на досягнення загальної мети. Вона має керуючу і керовану підсистеми та виконує функції планування, організації, мотивації і контролю. Відповідно до Закону України «Про охорону праці» [3], що визначає суть охорони праці, та «Рекомендацій щодо побудови, впровадження і удосконалення системи управління охороною праці» [4] системою управління охороною праці (СУОП) можна вважати упорядковану сукупність взаємозв'язаних «правових, соціально-економічних, організаційнотехнічних, санітарно-гігієнічних і лікувально-профілактичних заходів та засобів, що спрямовані на збереження життя, здоров’я і працездатності людини», та які «запобігають нещасним випадкам та професійним захворюванням на виробництві, а також небезпеці для третіх осіб».

СУОП передбачає підготовку, прийняття та реалізацію заходів, спрямованих на створення безпечних і комфортних умов праці. Її ефективність залежить від здатності реагувати на зовнішні зміни та адаптуватися до них. СУОП України є багаторівневою: державний, регіональний, галузевий та рівень суб'єктів господарювання (їх об’єднань). 
Між рівнями управління існують прямі і опосередковані взаємозв'язки. Якщо на етапах вироблення і реалізації управлінських дій існує достатньо чітка субординація від вищого до нижчого рівня системи, то на етапі формування завдань, їх реалізації та порівняння показників стану виконання завдань - довільний характер взаємодії рівнів системи. Так, нижчі рівні системи можуть використовувати інформацію про стан охорони праці будь-якого іншого рівня, а органи управління найвищого рівня одержують інформацію, як правило, безпосередньо від органів управління охороною праці підприємства [5].

Ефективність СУОП залежить від того, на скільки вона здатна адаптуватися та реагувати на: 1) державну політику та зміни у підходах до охорони праці; 2) структурні зміни у іiі підсистемах; 3) сучасні демографічні тенденції, технологічні, екологічні та технічні зміни, зміни у формах і методах організації праці.

Стан охорони праці на підприємствах України характеризується сукупністю показників, зокрема кількістю нещасних випадків на виробництві, динаміка яких за період 2015-2019 рр. відображена на рис.1.

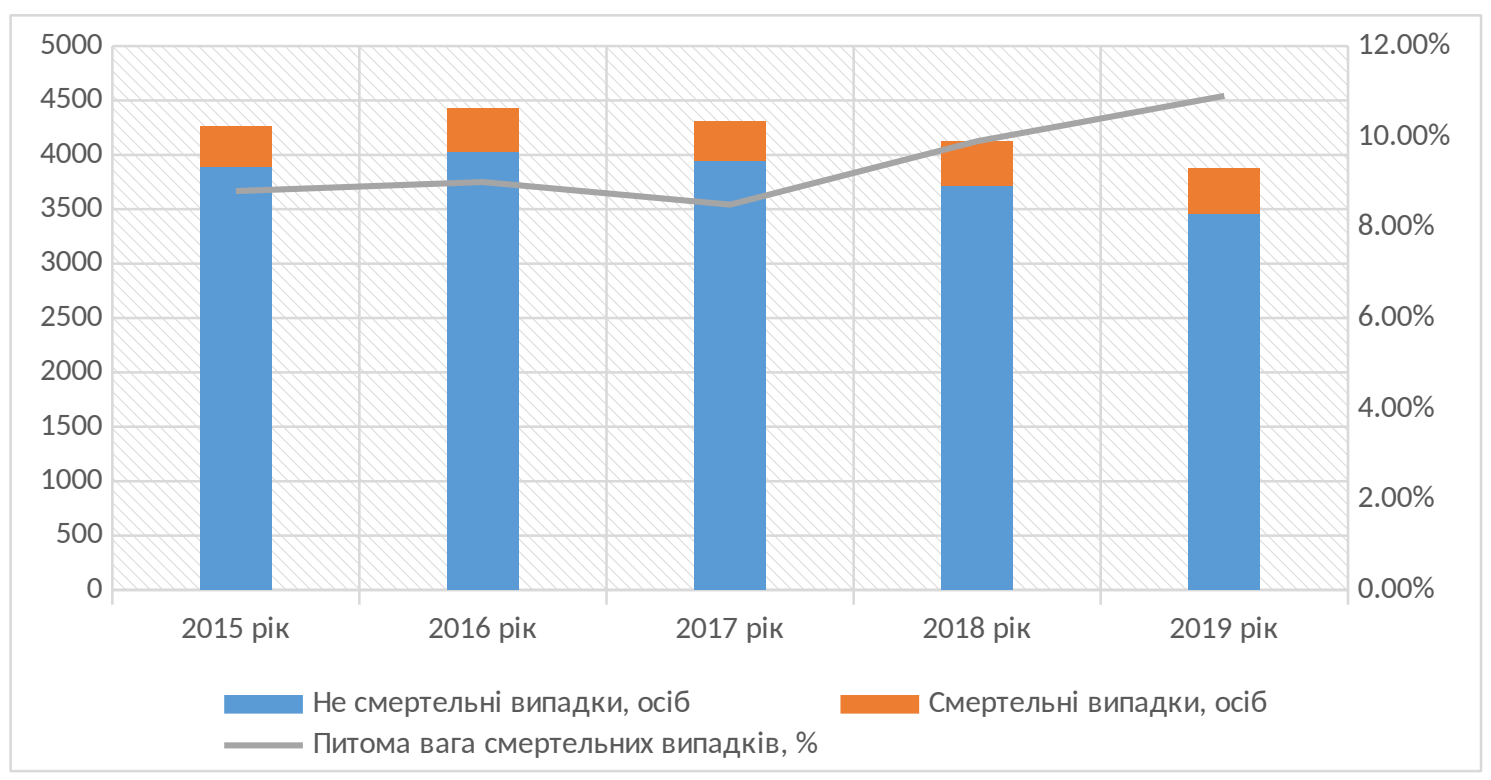

Рис. 1. Динаміка виробничого травматизму в Україні за 2015-2019 pp.

Джерело: складено за [6]

Загальна динаміка виробничого травматизму в Україні є нестабільною, але за 2016-2019 рр. кількість нещасних випадків знизилась на 14,2\%. Загрозливою $\epsilon$ тенденція щодо зростання смертельних нещасних випадків: якщо у 2017 р. їх частка становила 8,5\%, то у 2019 - 10,9\%. За період 10-30 січня 2020 р. кількість постраждалих від нещасних випадків в Україні становила 329 осіб, з них 79 - смертельні випадки, кількість повідомлень про професійні захворювання - 150. [7].

Отже, зменшення кількості нещасних випадків, які $\epsilon$ наслідком виробничого травматизму, з одного боку, може свідчити про позитивні зміни у СУОП, з іншого - $\epsilon$ наслідком впливу суб'єктивних факторів. Так, у 2014 р. відбулась реорганізація в державній системі управління охороною праці: Державній службі України з питань праці були передані функції Держгірпромнагляду, Державної інспекції праці та частково Держсанепідслужби. Це дозволило як скоротити загальну чисельність працівників і, відповідно, витрати, так і підвищити оперативність розв'язання проблем, що виникають в процесі здійснення господарської діяльності для всіх зацікавлених сторін. 
Натомість така динаміка загального офіційного травматизму може не відповідати реальному стану охорони праці, тому що:

1) зростає «неофіційний», тобто необлікований травматизм. Підприємства приховують нещасні випадки несмертельного характеру [8];

2) на фоні скорочення середньооблікової чисельності працівників показники зниження загального травматизму є значно меншими.

Проблема охорони праці стала об'єктом уваги з боку світового співтовариства у 1919 р. зі створенням Міжнародної організації праці як структурного підрозділу Ліги Націй. За 100 років існування МОП були зроблені відчутні кроки, які сприяли захисту життя і здоров'я працівників. Усі документи, що прийняті МОП відображають консенсус між державами-членами, представниками роботодавців та працівників.

За ступенем деталізації проблем трудових відносин, усі норми МОП, можна поділити на чотири групи [2].

1. Норми з ключових принципів трудових відносин: Конвенція про безпеку і гігієну праці (1981 р., №155) і Протокол до конвенції (2002 р.); Конвенція про служби гігієни праці (1985 р., №161); Конвенція про основи, що сприяють безпеці та гігієні праці (2006 р., №187).

2. Норми з загальних принципів охорони праці: управління охороною праці, інспекції праці, санітарно-побутові умови тощо.

3. Норми для видів економічної діяльності: сільське господарство, будівництво, хімічне виробництво, видобувні галузі тощо.

4. Норми для конкретних факторів ризику: азбест, білий фосфор, захист від радіації, хімічні речовини тощо.

Конвенції з ключових принципів трудових відносин є обов'язковими для всіх країн-членів МОП (зокрема і для України), норми з загальних принципів охорони праці - для країн-членів, що ратифікували їх і зобов'язалися включити у національні законодавства; практичні правила з трудових відносин для видів економічної діяльності та конкретних факторів ризику, що розроблені й узгоджені представниками трьох сторін, носять рекомендаційний характер і не мають обов'язкової юридичної сили. Так, для України є чинними 63 конвенції МОП, включно 38 основоположними і 4 пріоритетними [9].

Європейський вектор України сприяє реформуванню різних галузей економіки і сфер діяльності, зокрема ставлення до проблем охорони праці. Відомо, що крім економічних втрат виникають втрати нематеріального характеру, що «матеріалізуються» у психосоціальних та неінфекційних захворюваннях, які $\epsilon$ наслідком порушення умов праці на підприємствах [2].

Еволюція світової політики щодо охорони праці характеризувалась зміщенням пріоритетів у нормативно-правовому регулюванні від директивного підходу до попереджувальних і контролюючих заходів (60-ті роки XX ст.) та орієнтацією на системний підхід управління ризиками (80-ті роки XX ст.).

3 метою вдосконалення СУОП у 2018 році розпорядженням Кабінету Міністрів України № 989-р схвалена Концепція реформування системи управління охороною праці в Україні, в якій визначено принципи, напрями та завдання системи організації безпеки та гігієни праці з врахуванням ризикоорієнтованого підходу для забезпечення впровадження стандартів МОП. Концептуальними заходами передбачено перехід від політики реагування на небезпечні випадки на виробництві до політики їх профілактики. Основою реформування є норми Директиви № 89/391/ЄЕС щодо запровадження заходів для заохочення вдосконалення у сфері безпеки і охорони здоров'я працівників під час роботи, які визначають загальні принципи формування системи (запобігання ризикам, оцінювання тих, які неможливо уникнути; усунення ризиків тощо). 
Україна має адаптувати національне законодавчо-нормативне забезпечення 3 безпеки і гігієни праці до вимог директив ЄС. Стан імплементації міжнародних стандартів відображено у табл. 1 і 2 [10].

Таблиця 1

Директиви Європейського парламенту і Ради, основні положення яких враховані у національному законодавстві

\begin{tabular}{|c|c|}
\hline Директива & ністерства соціальної політики України \\
\hline $\begin{array}{l}1 . \quad \text { Директива } 2009 / 104 / € C \\
\text { Європейського парламенту і Ради від } \\
16.09 .2009 \text { р. }\end{array}$ & $\begin{array}{l}\text { «Про затвердження Вимог безпеки та захисту } \\
\text { здоров’я під час використання виробничого обладнання } \\
\text { працівниками» від } 28.12 .2017 \text { p. № } 2072 \text {. }\end{array}$ \\
\hline $\begin{array}{l}\text { 2. Директива Ради 92/57/СЕС від } \\
\text { 24.06. } 1992 \text { р. }\end{array}$ & $\begin{array}{l}\text { «Про затвердження Мінімальних вимог з охорони } \\
\text { праці на тимчасових або мобільних } \\
\text { майданчиках» від 23.06.2017p. № } 1050 .\end{array}$ \\
\hline $\begin{array}{l}\text { 3. Директива Ради } 89 / 656 / \text { EЕС } \\
\text { від 30.11.1989 р. }\end{array}$ & $\begin{array}{l}\text { «Про затвердження Мінімальних вимог безпеки i } \\
\text { охорони здоров’я при використанні працівниками засобів } \\
\text { індивідуального захисту на робочому місці» від } \\
\text { 29.11.2018 р. № } 1804 \text {. } \\
\end{array}$ \\
\hline $\begin{array}{l}\text { 4. Директива Ради 90/270/СЕС } \\
\text { від 29.05.1990 р. }\end{array}$ & $\begin{array}{l}\text { «Про затвердження Вимог щодо безпеки та } \\
\text { захисту здоров’я працівників під час роботи з екранними } \\
\text { пристроями» від } 14.02 .2018 \text { р. № } 207 \text {. }\end{array}$ \\
\hline $\begin{array}{l}\text { 5. Директива Ради 92/104/СЕС від } \\
\text { 3.12.1992 p. }\end{array}$ & $\begin{array}{l}\text { «Про затвердження Вимог щодо безпеки та та } \\
\text { захисту здоров’я працівників видобувних підприємств } 3 \\
\text { підземним і відкритим способами видобування» від } \\
\text { 02.07.2018 р. № } 943 . \\
\end{array}$ \\
\hline
\end{tabular}

Таблиця 2

Директиви Свропейського парламенту і Ради , які мають бути імплементовані

\begin{tabular}{|c|c|}
\hline Директива & Зміст \\
\hline $\begin{array}{l}\text { Директива Ради 89/391/СЕС від } \\
12.06 .1989 \text { p. }\end{array}$ & $\begin{array}{l}\text { Про впровадження заходів для заохочення } \\
\text { вдосконалення у сфері безпеки i охорони здоров'я } \\
\text { працівників під час роботи. }\end{array}$ \\
\hline $\begin{array}{l}\text { 2. Директива Ради 92/91/ЄЕС від } \\
3.11 .1992 \text { p. }\end{array}$ & $\begin{array}{l}\text { Про мінімальні вимоги для поліпшення безпеки } \\
\text { та охорони здоров’я працівників у видобувних галузях, } \\
\text { що використовують буріння. }\end{array}$ \\
\hline $\begin{array}{lllr}\text { 3.Директива } & \text { Ради } & \text { 89/654/СЕС } & \text { від } \\
30.11 .1989 \text { p. } & & & \end{array}$ & $\begin{array}{l}\text { Про мінімальні вимоги стосовно безпеки } \mathrm{i} \\
\text { охорони здоров’я на робочому місці. }\end{array}$ \\
\hline $\begin{array}{l}\text { 4. } \text { Директива } \\
\text { 24.06.1992 р. }\end{array}$ & $\begin{array}{cccc}\text { Про } & \text { мінімальні } & \text { вимоги } & \text { до } \\
\text { пабезпечення } \\
\text { позначень безпеки та/або гігієни на робочому місці. }\end{array}$ \\
\hline
\end{tabular}

Останнім часом процес наближення законодавства України до міжнародних стандартів сповільнився. Крім того, є певні проблеми щодо врахування міжнародних підходів, що може негативно вплинути на якість функціонування СУОП. Це зокрема: 1) вибір окремих фрагментів (директив) та їх імплементація не дозволить комплексно реформувати усі аспекти безпеки і гігієни праці; 2) урахування вимог директив переважно здійснюється у наказах, правова сила яких, є менш впливовою на відміну від законів чи постанов Кабміну України; 3) сформована не достатньо досконала система, що забезпечує застосування та дотримання вимог нормативних актів.

Основними змінами, що передбачені в Концепції та які можуть позитивно вплинути на СУОП, є [11]:

- забезпечення гендерної рівності у працевлаштуванні чоловіків і жінок, тобто відмова від переліку заборонених професій для жінок. У такому випадку для збереження репродуктивного здоров'я необхідно передбачити додаткову систему захисту для всіх осіб (незалежно від статті), хто працює у небезпечних умовах; 
- спроба врегулювати проблему безпечної праці робітників, які працюють на договірних засадах і виконують роботи на одному робочому (підрядний та субпідрядний договір на виконання робіт, аутсорсинг). Механізмом може бути створення спільних представницьких органів (комітетів) роботодавців з питань безпеки та гігієни праці;

- посилення відповідальності роботодавців за нелегальну (неофіційну) працю, що використовується на підприємствах 3 високим ступенем небезпеки, через підвищення штрафних санкцій;

- удосконалення фінансового механізму виплат за нещасні випадки на виробництві та їх приховування. Ефективним може бути механізм поєднання штрафів, виплат держави та додаткових фінансових зобов'язань роботодавців перед постраждалими особами чи їх родинами.

Деякі зміни, що можуть бути реалізовані у межах Концепції, є неоднозначними щодо підвищення ефективності СУОП. Це зокрема:

1) продовження процесу дерегуляції через зменшення адміністративного i регуляторного навантаження на роботодавця, зокрема 3 питань безпеки та гігієни праці. Мораторій на перевірки бізнесу призвів до зловживань 3 боку бізнесу і втрат на виробництві. У 2017 р. було скасовано понад 120 нормативно-правових актів як таких, що втратили свою правову обгрунтованість, зокрема у сфері пожежної та техногенної безпеки. Вони не були замінені новими, тому це створює проблеми у виконанні функцій контролю 3 питань охорони праці. Подальша дерегуляція може призвести до загострення проблеми в галузі безпеки праці [12];

2) переміщення функцій розробки правил з безпеки та охорони праці і контролю за їх виконанням від держави в особі Держпраці до роботодавців. Цей крок не можна вважати таким, що зменшить корупційні прояви і тиск на роботодавців, проте він відкриває «нові можливості» для зловживань та їх приховування з боку підприємців;

3) розширення повноважень інспекторів щодо покарань порушників правил 3 охорони праці (від усних попереджень до штрафів), що може бути корупційним джерелом.

Нові законодавчі ініціативи щодо реформування трудових відносин в Україні мають враховувати і підсилювати основні тенденції у питаннях безпеки та гігієни праці. Крім того, політика в галузі охорони праці має бути послідовною і передбачуваною. Це стосується зокрема проєкту Закону України «Про працю», який було відкликано у зв'язку зі зміною Кабінету Міністрів. Його положення, що були винесені на обговорення і затвердження,:

1) послаблюють рівень охорони праці як у порівнянні з чинним національним законодавством (у частині заборони укладати трудовий договір на виконання робіт у важких, шкідливих і небезпечних умовах праці, умовах підвищеного ризику для життя і здоров'я 3 неповнолітніми і не поширюється на вагітних жінок, а також жінок, які годують груддю), так і у порівнянні з вимогами, що передбачені Директивою Ради 2000/78/СС, яка містить гарантії щодо організації безпечного ведення роботи та вжиття заходів із збереження життя та здоров'я працівника з боку роботодавця, що відсутнє у проекті закону [13];

2) зменшують роль договірного регулювання колективних трудових відносин і надання пріоритету роботодавцю та індивідуальним трудовим договорам [14], нівелюють роль профспілок, що може негативно позначитися і на безпеці праці.

Ефективність функціонування СУОП залежіть не лише від рішень, що реалізуються у межах державної політики, але і від дій суб'єктів господарювання та їх зацікавленості щодо поліпшення умов та безпеки праці своїх працівників. Джерелом виникнення небезпеки $є$ саме господарська діяльність. Від того, як взаємодіють роботодавці і працівники у питаннях безпеки та гігієни праці, буде залежати іiі результат. 
Результативність охорони праці передбачає залучення всіх учасників трудового процесу - від керівника підприємства до робітників. Їх взаємодія має базуватися на мотивації, еволюція якої має чотири рівні (крива Бредлі). Перший рівень $є$ реактивним. Він грунтується на природних інстинктах самозбереження, проте не призводить до зниження травматизму. Другий - залежний, у якому присутній контроль і примус 3 боку керівних органів щодо виконання необхідних правил і який може забезпечити лише незначний результат. Третій - незалежний, що створює умови для усвідомлення працівником особистої безпеки, формування практичних звичок та індивідуального визнання за безпечну роботу. Мотивація такого рівня може дати достатньо високий результат щодо зниження виробничого травматизму. Найвищим рівнем є четвертий (взаємозалежний), який формує колективну безпеку, взаємодопомогу, командну роботу. Він базується переважно на позитивних мотиваціях, таких як грошова, моральна, визнання досягнень колективу і кожного у створенні безпечних умов праці. Такий підхід може до мінімуму зменшити виробничий травматизм.

Більшість вітчизняних підприємств перебуває на другому рівні в культурі безпеки, про що свідчать слова голови Союзу захисту підприємництва С. Доротича, який вважає, що робітника не можливо переконати у необхідності використовувати засоби індивідуального захисту навіть методами примусу (штраф тощо), тому робити відповідальним за наслідки роботодавця $\epsilon$ несправедливим [15]. Такий підхід роботодавців до питань охорони праці не дозволить розв'язати проблему і потребує корегування їх свідомості через поширення і популяризацію передового досвіду тих підприємств, які використовують колективну позитивну мотивацію, спрямовану на створення організаційних умов безпечної праці.

МОП окреслила основні трансформації, які відбуваються в світі і які призведуть до змін у сфері охорони праці. Це: технологія, демографічна ситуація, зміни клімату і організації праці. Вони створюють як нові можливості, так і виклики щодо безпеки праці.

1. Вважається, що у сфері праці відбувається «четверта індустріальна революція», яка продукує цифрову техніку, інформаційні та комунікативні технології, засоби автоматизації, робототехніку, нанотехнології. Такі технологічні зміни спричиняють психосоціальні і ергономічні ризики, ризики безпеки приватного життя i небезпеки впливу хімічних, біологічних та електромагнітних факторів тощо.

2. У робочій силі відбуваються зміни ії вікових характеристик і гендерного складу, посилюються міграційні процеси. Найбільш високий рівень травматизму спостерігається у працівників віком до 24 років та понад 65. Так, у Європі рівень несмертельного виробничого травматизму у цих вікових групах на $40 \%$ вище ніж у інших, у США - у двічі. Прогнозується, що частка працівників віком понад 65 років до 2050 р. зросте до 16\%. Крім того, існує гендерна нерівність щодо працевлаштування жінок, тому вони, як правило, охоплені нестандартними формами зайнятості, а 57\% зайнятих працюють неповний робочий день [2]. Усі ці обставини призводять до виникнення нових ризиків в галузі охорони праці, на які необхідно завчасно реагувати.

За даними МОП процесами міжнародної трудової міграції за період 2013-2017 pp. було охоплено понад 164 млн осіб, більшість 3 яких виконує небезпечну, низькокваліфіковану роботу і зайнята у неформальній економіці. Це призводить до підвищення професійних ризиків і викликає необхідність розробки механізмів, що дозволять розв'язати такі проблеми.

3. Зміни клімату, які відбуваються внаслідок діяльності людини, змінюють і ії сферу праці. Це матиме негативні наслідки для охорони праці (особливо в сільському, лісовому господарствах та будівництві) і тому потребує оперативного реагування та попереджувальних заходів.

Динамічний розвиток галузей «зеленої» економіки змінює структуру і характер зайнятості та призводить до виникнення нових ризиків у безпеці та гігієні праці, що також потребує відповідного реагування. 
4. Серйозним викликом для охорони праці є зміни в іiі організації, які пов’язані 3 переходом від формальної до неформальної форм зайнятості у вигляді нестандартних форм, де працівники працюють за тимчасовими, субпідрядними контрактами (часто багаторівневими) в інших країнах, дистанційна і мобільна робота, цифрові робочі платформи тощо. Усе це потребує врегулювання трудових відносин і захисту від небезпек, що виникають.

Висновки. Отже, аналіз СУОП в Україні дозволяє зробити такі висновки:1) стан охорони праці в Україні викликає занепокоєння, тому що зберігається стійка тенденція до зростання кількості нещасних випадків із смертельним наслідком, приховування випадків виробничого травматизму, що свідчить про недосконалість системи; 2) процес реформування СУОП здійснюється непослідовно, фрагментарно і недостатньо динамічно; 3) наявність численних нормативних i законодавчих актів, у яких унормовуються різні аспекти охорони праці, не підвищує оперативність переходу від концепції реагування на нещасні випадки до концепції їх запобігання.

3 метою підвищення ефективності функціонування СУОП необхідно: 1) оптимізувати кількість нормативно-законодавчих актів в галузі охорони праці та підвищити їх дієвість через прийняття та удосконалення відповідних законів, усунувши протиріччя; 2) забезпечити баланс між: а) інтересами роботодавців і найманих працівників у питаннях відповідальності, попередження і оперативності реагування; б) державою i роботодавцями у питаннях фінансування заходів та контролю за виконанням рішень; 3) спростити механізм зупинки небезпечного виробництва та процедуру відмови працівника від роботи у випадку загрози небезпеки; 4) врахувати сучасні трансформаційні зміни у сфері праці та: а) подолати вузькопрофільний підхід до проблеми охорони праці загалом і безпеки та гігієни праці зокрема, поєднавши спеціалістів з права, інженерно-технічного забезпечення, організації праці, медицини, нейробіології тощо; б) підвищити рівень компетентності з питань охорони праці через формальну і неформальну освіту упродовж всього життя; в) формувати національну культуру профілактики за активної участі уряду, роботодавців і найманих працівників; г) інтегрувати у трудове законодавство та СУОП механізм забезпечення інтересів працівників з нестандартними формами зайнятості для захисту їх здоров’я і життя; д) для створення безпечного та здорового середовища підвищити роль уряду, неурядових організацій, роботодавців, об'єднань працівників, громадськості.

\section{Список бібліографічного опису:}

1. Населення та міграція URL: http://www.ukrstat.gov.ua/. (Дата звернення 02.02.2020)

2. Охорона праці - основа майбутнього сфери праці (Звіт MOП) URL: https://www.ilo.org/wcmsp5/groups/public/---europe/--ro-geneva/---sro-moscow/documents/publication/wcms_693749.pdf. (Дата звернення 02.02.2020)

3. Закон України «Про охорону праці», ред. від 27.12.2019 p. URL: https://zakon.rada.gov.ua/laws/show/2694-12. (Дата звернення 05.02.2020)

4. Рекомендацій щодо побудови, впровадження та удосконалення системи управління охороною праці URL: http://consultant.parus.ua/?doc=04OF34FC76. (дата звернення 05.03.2020)

5. Загальні положення системи управління охороною https://pidruchniki.com/12281128/bzhd/sistema_upravlinnya_ohoronoyu_pratsi_ukrayini. (Дата звернення 10.02.2020)

6. Інформація державної служби України з питань праці URL: http://dsp.gov.ua/statystychni-dani-vyrobnychoho-travma-2/. (Дата звернення 02.02.2020)

7. Інформація Фонду соціального страхування URL: http://www.fssu.gov.ua/fse/control/main/uk/publish/article/967134;jsessionid=. (Дата звернення: 02.02.2020)

8. Чернега Р. Державна служба України з питань праці: завдання, перспективи, досягнення. Матеріали III міжнародної науковопрактичної конференції «Промислова безпека: найкращі практики-2015». Львів. (6-8 жовтня). с.12.

9. Офіційний сайт MOП URL: https://www.ilo.org/dyn/normlex/en/f?p=1000:11200:0: (Дата звернення 10.02.2020)

10.Сантуш А. Узгодження українського законодавства з європейською нормативно-правовою базою з безпеки і гігієни праці: ключові питання URL: http://oppb.com.ua/articles/uzgodzhennya-ukrayinskogo-zakonodavstva-z-yevropeyskoyu-normatyvno-pravovoyubazoyu-z-0. (Дата звернення 20.02.2020)

11.Дудін В. Чи стартує у 2019 р. Реформа охорони праці і яка саме? URL: https://rev.org.ua/chi-startuye-u-2019-r-reforma-oxoronipraci-i-yaka-same/. (Дата звернення 20.02.2020)

12.Дудін В. Дерегуляція чи депопуляція? 10 питань про контроль URL: https://rev.org.ua/deregulation-or-depopulation-2/. (Дата звернення 01.03.2020)

13.Висновок Комітету Верховної Ради України з питань інтеграції України з ЄС щодо проекту Закону «Про працю» URL: http://w1.c1.rada.gov.ua/pls/zweb2/webproc4_1?pf3511=67833. (Дата звернення: 01.03.2020) 
14.Реформування трудового законодавства: резолюція круглого столу URL: https:/hrliga.com/index.php? module=news\&op=view\&id=21384. (Дата звернення 05.03.2020)

15.Ермоленко А. Инспекторы по охране труда получат сверхполномочия и будут по-новому штрафовать бизнес URL: https:/ubr.ua/labor-market/ukrainian-labor-market/inspektory-po-okhrane-truda-poluchat-sverkhpolnomochija-i-budut-po-novomushtrafovat-biznes-. (Дата звернення 05.03.2020)

\title{
References:
}

1. Naselennia ta mihratsiia URL: http://www.ukrstat.gov.ua/. (Data zvernennia 02.02.2020)

2. Okhorona pratsi - osnova maibutnoho sfery pratsi (Zvit MOP) URL: https://www.ilo.org/wcmsp5/groups/public/---europe/---ro-geneva/--sro-moscow/documents/publication/wcms_693749.pdf. (Data zvernennia 02.02.2020)

3.Zakon Ukrainy «Pro okhoronu pratsi», red. vid 27.12.2019 r. URL: https://zakon.rada.gov.ua/laws/show/2694-12. (Data zvernennia 05.02.2020)

4. Rekomendatsii shchodo pobudovy, vprovadzhennia ta udoskonalennia systemy upravlinnia okhoronoiu pratsi URL: http://consultant.parus.ua/?doc=04OF34FC76. (data zvernennia 05.03.2020)

5.Zahalni polozhennia systemy upravlinnia okhoronoiu https://pidruchniki.com/12281128/bzhd/sistema_upravlinnya_ohoronoyu_pratsi_ukrayini. (Data zvernennia 10.02.2020)

6. Informatsiia derzhavnoi sluzhby Ukrainy $\mathrm{Z}$ pytan pratsi URL: http://dsp.gov.ua/statystychni-dani-vyrobnychoho-travma-2/. (Data zvernennia 02.02.2020)

$\begin{array}{lcc}\text { 7. Informatsiia } & \text { Fondu } & \text { sotsialnoho } \\ \text { http://www.fssu.gov.ua/fse/control/main/uk/publish/article/967134;jsessionid=. (Data zvernennia 02.02.2020) }\end{array}$

8. Cherneha R. Derzhavna sluzhba Ukrainy z pytan pratsi: zavdannia, perspektyvy, dosiahnennia. Materialy III mizhnarodnoi naukovopraktychnoi konferentsii «Promyslova bezpeka: naikrashchi praktyky-2015». Lviv. (6-8 zhovtnia). s.12.

9. Ofitsiinyi sait MOP URL: https://www.ilo.org/dyn/normlex/en/f?p=1000:11200:0: (Data zvernennia 10.02.2020)

10. Santush A. Uzghodzhennia ukrainskoho zakonodavstva $\mathrm{z}$ yevropeiskoiu normatyvno-pravovoiu bazoiu $\mathrm{z}$ bezpeky $\mathrm{i}$ hihiieny pratsi: kliuchovi pytannia URL: http://oppb.com.ua/articles/uzgodzhennya-ukrayinskogo-zakonodavstva-z-yevropeyskoyu-normatyvno-pravovoyubazoyu-z-0. (Data zvernennia 20.02.2020)

11. Dudin V. Chy startuie u 2019 r. Reforma okhorony pratsi i yaka same? URL: https://rev.org.ua/chi-startuye-u-2019-r-reforma-oxoronipraci-i-yaka-same/. (Data zvernennia 20.02.2020)

12. Dudin V. Derehuliatsiia chy depopuliatsiia? 10 pytan pro kontrol URL: https://rev.org.ua/deregulation-or-depopulation-2/. (Data zvernennia 01.03.2020)

13. Vysnovok Komitetu Verkhovnoi Rady Ukrainy z pytan intehratsii Ukrainy z YeS shchodo proektu Zakonu «Pro pratsiu» URL: http://w1.c1.rada.gov.ua/pls/zweb2/webproc4_1?pf3511=67833. (Data zvernennia 01.03.2020)

14. Reformuvannia trudovoho zakonodavstva: rezoliutsiia kruhloho stolu URL: https:/hrliga.com/index.php? module $=$ news\&op=view\&id=21384. (Data zvernennia 05.03.2020)

15. Ermolenko A. Ynspektorb po okhrane truda poluchat sverkhpolnomochyia y budut po-novomu shtrafovat byznes URL: https:/ubr.ua/labor-market/ukrainian-labor-market/inspektory-po-okhrane-truda-poluchat-sverkhpolnomochija-i-budut-po-novomu-

shtrafovat-biznes-. (Data zvernennia 05.03.2020)

Дата подання публікації 18.03 .2020 p.

УДК 338.48-6.615.8

Матвійчук Л.Ю, д.е.н., професор,

Matviichuk L. Doctor of Economic Sciences, Professor http://orcid.org/0000-0003-1694-6178

Чепурда Л.М., д.е.н., професор

Chepurda L. Doctor of Economic Sciences, Professor http://orcid.org/0000-0002-8941-9427

\section{ФОРМУВАННЯ ДОСТУПНОГО СЕРЕДОВИЩА ІНКЛЮЗИВНОГО ТУРИЗМУ}

\author{
Луиький національний технічний університет \\ Черкаський державний технологічний університет
}

Інклюзивний туризм достатньо новий напрямок дослідження, у порівнянні з рекреаційним чи пізнавальним туризмом. Проте, трактування та значення понять, які визначають зміст дефініції «інклюзивний туризм», є предметом наукових дискусій. Аналіз світового досвіду засвідчив, що туристи 3 особливими потребами займають важливий сегмент туристичного ринку. Інклюзивний туризм $\epsilon$ необхідним видом туризму у кожному туристичному регіоні різних рівнів. Це один 3 найбільш інтенсивно розвиваючих видів туризму.

Детального аналізу потребує визначення змісту інклюзивного туризму, теоретичних та прикладних аспектів формування доступного середовища зазначеного виду туризму зважаючи на його специфіку.

В статті проаналізовані підходи вчених до трактування поняття «інклюзивний туризм», визначено ключові критерії змістовного наповнення досліджуваного виду туризму (адаптивність, 
комунікативність, доступність, відповідність, безпека, інфраструктура та раціональність). Проведено аналіз змісту та значення доступного середовища інклюзивного туризму, доведено доцільність його формування, визначено ключові компоненти такого середовища (інституційні, просторові, інформаційні, комунікативно-організаційні). Доведено, що в інклюзивному туризмі, ключову роль відіграють туристичні суб'єкти - туристи, для якого надаються туристичні послуги та фахівці - які надають зазначені туристичні послуги або продають туристичні продукти. Визначено власне бачення поняття «інклюзивний туризм» як специфічний (безпечний) вид туризму, основною метою якого є безбар'єрний доступ до усіх туристичних ресурсів, позитивний психологічний клімат, рівність можливостей усіх туристів, повномасштабне інформування людей з особливими потребами про можливості того чи іншого туристичного об'єкту, а також передбачає швидку здатність суб'єктів туризму перелаштовуватись відповідно до запитів людей з особливими потребами.

Ключові слова: інклюзія, доступне середовище, туризм для всіх, безпека. 